\title{
PENGARUH PENGGUNAAN MEDIA VIDEO PEMBELAJARAN TERHADAP HASIL BELAJAR IPS MATERI KERAGAMAN KENAMPAKAN ALAM DAN BUATAN INDONESIA PADA SISWA KELAS V SEKOLAH DASAR Anggra Lita Sandra Dewi ${ }^{1}$, Lailatul Mubarokah ${ }^{2}$ ${ }^{1,2)}$ STKIP PGRI Sidoarjo \\ E-mail: ${ }^{1)}$ akusandradewi1989@gmail.com \\ ${ }^{2)}$ lailatulm11@gmail.com
}

\begin{abstract}
Abstrak: Penelitian ini bertujuan untuk mengetahui pengaruh media video pembelajaran terhadap hasil belajar IPS materi keragaman kenampakan alam dan buatan Indonesia pada siswa kelas V Sekolah Dasar. Penelitian ini dilakukan di SDN Jatijejer Trawas-Mojokerto dengan subjek penelitian adalah siswa kelas VA dan VB tahun pelajaran 2018/2019. Jenis penelitian yang dilakukan adalah penelitian eksperimen dengan bentuk desain penelitian pretest-posttest control group design. Instrumen yang digunakan untuk mengumpulkan data adalah soalsoal hasil belajar. Butir soal variabel hasil belajar telah diuji cobakan melalui uji validitas menggunakan korelasi Product Moment dan uji reliabilitas menggunakan Alpha Cronbach's dengan hasil yang valid dan reliabel. Uji normalitas data menggunakan Kolmogorov Smirnov, sedangkan uji homogenitas dan pengujian hipotesis menggunakan rumus Independent Sample t test dengan hasil kedua kelas berdistribusi normal dan homogen. Data-data yang telah berhasil dikumpulkan kemudian dianalisa dengan analisis $\mathrm{Uji} t$ dengan memanfaatkan komputer dengan sistem seri program statistik (SPSS version 17). Hasil uji hipotesis pertama menunjukkan bahwa hasil belajar siswa pada kelas eksperimen lebih tinggi dibandingkan pada kelas kontrol. Hal ini ditunjukkan oleh nilai sig. sebesar $0,000<\alpha 0,05$ dan $t_{\text {hitung }}(7,372)<t_{\text {tabel }}(1,684)$ dengan nilai mean sebesar 59.8400 dibandingkan dengan hasil belajar siswa dengan menggunakan metode ceramah yaitu 48,9800. Dengan demikian dapat disimpulkan bahwa media video pembelajaran berpengaruh terhadap hasil belajar IPS materi keragaman kenampakan alam dan buatan Indonesia pada siswa kelas V Sekolah Dasar secara signifikan.
\end{abstract}

Kata kunci: Media Video, Hasil Belajar, Keragaman Kenampakan Alam dan Buatan Indonesia

Abstract: This study aims to determine the effect of instructional video media on social studies learning outcomes in the diversity of natural and Indonesianmade material appearance in fifth grade students of elementary schools. This research was conducted at SDN Jatijejer Trawas-Mojokerto with the research subjects being VA and VB grade students in the 2018/2019 academic year. This type of research is an experimental study in the form of a pretest-posttest control group design research design. The instrument used to collect data is learning outcomes. Item learning outcomes variables have been tested through the validity test using Product Moment correlation and reliability testing using Cronbach's Alpha with valid and reliable results. Data normality test uses Kolmogorov Smirnov, while homogeneity test and hypothesis testing use the formula of Independent Sample t test with the results of both classes having normal and homogeneous distribution. The data that has been successfully collected is then analyzed by t-test analysis using a computer with a statistical program series system (SPSS version 17). The results of the first hypothesis test showed that student learning outcomes in the experimental class were higher than in the control class. This is indicated by the value of sig. of $0,000<\alpha 0,05$ and tcount $(7,372)<$ ttable $(1,684)$ with a mean value of 59,8400 compared with student learning outcomes using the lecture method which is 48,9800 . Thus it 


\section{ELSE (Elementary School Education Journal) \\ Volume 3 Nomor 2 Agustus 2019}

P-ISSN: 2581-1800 E-ISSN: 2597-4122

Email: else@um-surabaya.ac.id

can be concluded that the instructional video media influences the learning outcomes of social studies material on the diversity of natural and Indonesianmade appearance in grade $\mathrm{V}$ students of elementary schools significantly.

Keywords: Video Media, Learning Outcomes, Diversity of Nature and Made in Indonesia

Submitted on: 2019-08-06 Accepted on: 2019-08-26

\section{PENDAHULUAN}

Setiap orang mengalami proses belajar di sepanjang hidupnya. Proses pembelajar dapat terjadi dimana saja, baik didalam lingkungan keluarga, sekolah maupun di masyarakat. Proses pembelajar itu sendiri adalah proses yang didalamnya terdapat kegiatan interaksi anatara guru-siswa dan komunikasi timbal balik yang berlangsung dalam situasi edukatif untuk mencapai tujuan belajar (Rustman, 2001:461).

Pendidikan merupakan suatu usaha sadar dan terencana untuk mengembangkan potensi siswa secara aktif menuju perubahan ke arah yang lebih baik. Seiring dengan berkembangnya zaman modern dan mengedepankan teknologi dalam setiap peningkatan kualitas pendidikan seperti saat ini dirasa perlu adanya pembaharuan sistem pembelajaran untuk meningkatkan kualitas penyelenggara pendidikan di lingkungan sekolah. Pada awalnya teknologi seperti LCD, Proyektor, VCD, komputer adalah barang mewah yang jarang dimiliki oleh masyarakat, tetapi saat ini sudah menjadi barang umum dikonsumsi baik secara pribadi, hiburan, atau di kantor/ perusahaan namun juga produk kemajuan teknologi ini juga merambah dunia pendidikan. Dengan adanya kehadiran teknologi modern maka sekolah dituntut untuk lebih kreatif dan inovatif dalam menyelenggarakan pendidikan dalam proses pembelajaran maupun menunjang pengguanaan media pembelajaran sehingga siswa lebih tertarik dalam mengikuti proses pembelajaran serta merasa senang dalam kegiatan pembelajaran dan diharapkan dapat mendapatkan hasil belajar yang maksimal.

Ilmu Pengetahuan Sosial (IPS) adalah salah satu mata pelajaran yang diberikan di jenjang Sekolah Dasar (SD). IPS sendiri merupakan cabang ilmu yang mempelajari hubungan manusia dengan lingkungannya dan juga kehidupan sosial di masyarakat. Dari analisis penguasaan materi Keragaman Kenampakan Alam dan Buatan Indonesia masih banyak siswa yang memperoleh nilai belum tuntas. siswa cenderung tidak paham jika disuruh oleh guru untuk mendeskripsikan macam-macam Keragaman Kenampakan Alam dan Buatan Indonesia dengan bahasanya sendiri. Hal ini dibuktikan dari hasil observasi dan 


\section{ELSE (Elementary School Education Journal) \\ Volume 3 Nomor 2 Agustus 2019 \\ P-ISSN: 2581-1800 E-ISSN: 2597-4122 \\ Email:else@um-surabaya.ac.id}

catatan lapangan yang telah diperoleh oleh penulis pada hari Senin, 5 Maret 2018 di kelas V SDN Jatijejer Trawas-Mojokerto TA 2018-2019, guru kurang kreatif dan inovatif dalam menyampaikan materi pembelajaran, hal ini diperkuat dengan data hasil belajar siswa yang diperoleh dari wali kelas $\mathrm{V}$ tentang pembelajaran materi Keragaman Kenampakan Alam Dan Buatan Indonesia yang sangat rendah. Hasil pembelajaran diketahui dari siswa yang kurang dari Kriteria Ketuntasan Minimal (KKM) yang telah ditentukan, yaitu ada 26,67\% siswa yang memperoleh nilai antara $75-90,73,33 \%$ siswa memperoleh nilai $<75$. Sedangkan KKM yang ditentukan di SDN Jatijejer Trawas Mojokerto TA 2018-2019 mata pelajaran IPS adalah 75,00. Dari hasil ulangan siswa tersebut proses belajar belum bisa dikatakan tuntas dan tujuan pembelajaran belum tercapai. Maka peneliti dianggap perlu memperkenalkan, memahami, mengembangkan dan menerapkan media video pembelajaran untuk mengetahui pengaruhnya terhadap hasil belajar IPS materi Keragaman Kenampakan Alam dan Buatan Indonesia pada Siswa Kelas V Sekolah Dasar.

\section{METODE PENELITIAN}

Jenis penelitian ini adalah Penelitian Eksperimen. Penelitian ini memiliki 2 variabel, yakni variabel bebas (independent) dan variabel terikat (dependent). Dalam penelitian eksperimen, variabel bebas (independent) merupakan variabel yang (mungkin) menyebabkan, memengaruhi, atau berefek pada outcome (Cresswell, 2012: 77). Variabel bebas dalam penelitian ini adalah penggunaan media video pembelajaran. Sedangkan variabel terikat merupakan variabel-variabel yang bergantung pada variabel-variabel bebas. Variabel dalam terikat dalam penelitian ini adalah hasil belajar siswa. Dalam penelitian ini, peneliti akan mengujicobakan penelitiannya ke dalam kelas eksperimen dan kelas kontrol. Pada kelas eksperimen akan menggunakan media video pembelajaran sedangkan pada kelas kontrol akan menerapkan pembelajaran menggunakan metode ceramah (tanpa mendapat perlakuan). Jenis penelitian kuantitatif yang akan dilaksanakan adalah jenis penelitian eksperimen karena bertujuan untuk mengukur pengaruh variabel bebas yaitu penggunakan media video pembelajaran $(\mathrm{X})$ terhadap variabel terikat hasil belajar (Y). 


\section{HASIL DAN PEMBAHASAN}

\section{Hasil Penelitian}

a. Hasil Validasi Rencana Pelaksanaan Pembelajaran (RPP)

Tabel 1. Hasil Validasi Rencana Pelaksanaan Pembelajaran

\begin{tabular}{|c|c|c|c|c|c|}
\hline \multirow{2}{*}{ NO. } & \multirow{2}{*}{ ASPEK YANG DINILAI } & \multicolumn{2}{|c|}{ Skor } & \multirow{2}{*}{\multicolumn{2}{|c|}{$\begin{array}{c}\text { Rata-rata } \\
\text { Kategori }\end{array}$}} \\
\hline & & Validator 1 & Validator 2 & & \\
\hline \multirow[t]{4}{*}{$\mathbf{I}$} & Perumusan Indikator & & & & \\
\hline & Keberhasilan Belajar & & & & \\
\hline & 1. Kejelasan rumusan & 4,00 & 3,00 & 3,50 & Baik \\
\hline & 2. Apersepsi & 4,00 & 4,00 & 3,50 & Baik \\
\hline \multirow[t]{3}{*}{ II } & Pemilihan dan Pengorganisasian & & & & \\
\hline & $\begin{array}{l}\text { 1. Ketepatan } \\
\text { pemilihan materi }\end{array}$ & 4,00 & 4,00 & 4,00 & Baik \\
\hline & 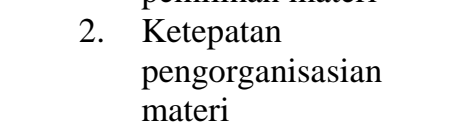 & 4,00 & 4,00 & 4,00 & Baik \\
\hline \multirow[t]{3}{*}{ III } & $\begin{array}{l}\text { Pemilihan Sumber Belajar dan } \\
\text { Media Pengajaran }\end{array}$ & & & & \\
\hline & $\begin{array}{l}\text { 1. Ketepatan } \\
\text { pemilihan sumber } \\
\text { belajar }\end{array}$ & 4,00 & 4,00 & 4,00 & Baik \\
\hline & $\begin{array}{l}\text { 2. Ketepatan } \\
\text { pemilihan media } \\
\text { pengajaran }\end{array}$ & 4,00 & 4,00 & 4,00 & Baik \\
\hline \multirow[t]{4}{*}{ IV } & Metode Pembelajaran & & & & \\
\hline & $\begin{array}{l}\text { 1. Kelengkapan tahapan- } \\
\text { tahapan pembelajaran }\end{array}$ & 4,00 & 3,50 & 3,00 & Baik \\
\hline & $\begin{array}{l}\text { 2. Kejelasan langkah- } \\
\text { langkah pembelajaran } \\
\text { untuk setiap tahap. }\end{array}$ & 3,00 & 4,00 & 3,50 & Baik \\
\hline & $\begin{array}{l}\text { 3. Kesesuain jenis } \\
\text { pembelajaran dengan } \\
\text { perkembangan anak }\end{array}$ & 3,00 & 3,50 & 3,25 & Baik \\
\hline \multirow[t]{3}{*}{$\mathbf{V}$} & Penilaian & & & & \\
\hline & 1. Kejelasan prosedur & 4,00 & 4,00 & 4,00 & Baik \\
\hline & $\begin{array}{l}\text { 2. Ketepatan jenis } \\
\text { penilaian }\end{array}$ & 3,00 & 3,50 & 3,25 & Baik \\
\hline \multirow[t]{5}{*}{ VI } & $\begin{array}{l}\text { Penggunaan Bahasa Tulis dan } \\
\text { Tampilan Dokumen }\end{array}$ & & & & \\
\hline & $\begin{array}{l}\text { 1. Ketepatan penggunaan } \\
\text { tulis dan tampil } \\
\text { dokumen }\end{array}$ & 4,00 & 4,00 & 4,00 & Baik \\
\hline & 2. Kelayakan tampilan & 4,00 & 4,00 & 4,00 & Baik \\
\hline & Skor Total & 49,00 & 49,50 & 49,25 & Baik \\
\hline & Skor Rata-rata & 3,77 & 3,81 & 3,79 & Baik \\
\hline
\end{tabular}

Sumber: data yang sudah diolah.

Hasil validasi RPP menunjukkan bahwa rata-rata validasi kelayakan RPP dari validator adalah dengan kategori baik, maka dapat disimpulkan bahwa kategori RPP baik dan layak digunakan dengan sedikit revisi. 


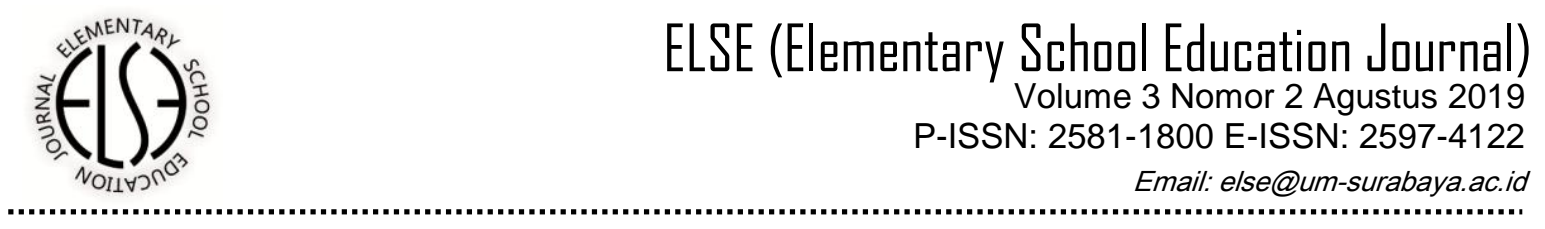

b. Hasil Validasi Tes Hasil Belajar (THB)

Tabel 2. Hasil Validasi Tes Hasil Belajar

\begin{tabular}{|c|c|c|c|c|c|c|c|}
\hline \multirow{3}{*}{ No } & \multicolumn{6}{|c|}{ Validitas } & \multirow{3}{*}{$\begin{array}{c}\text { Penilaian } \\
\text { Peneliti }\end{array}$} \\
\hline & \multicolumn{2}{|c|}{ Isi } & \multicolumn{2}{|c|}{ Bahasa dan Penulisan Soal } & \multicolumn{2}{|c|}{ Kesimpulan dari Validator } & \\
\hline & Validator I & Validator II & Validator I & Validator II & Validator I & Validator II & \\
\hline 1 & $\mathrm{~V}$ & V & $\mathrm{Dp}$ & $\mathrm{Dp}$ & $\operatorname{Tr}$ & $\mathrm{Tr}$ & Tanpa revisi \\
\hline 2 & $\mathrm{~V}$ & $\mathrm{~V}$ & $\mathrm{Dp}$ & $\mathrm{Dp}$ & $\operatorname{Tr}$ & $\operatorname{Tr}$ & Tanpa revisi \\
\hline 3 & $\mathrm{~V}$ & $\mathrm{~V}$ & Dp & Dp & $\operatorname{Tr}$ & $\operatorname{Tr}$ & Tanpa Revisi \\
\hline 4 & $\mathrm{CV}$ & V & Cdp & Dp & Rk & $\operatorname{Tr}$ & Revisi \\
\hline 5 & $\mathrm{~V}$ & V & Dp & Dp & $\operatorname{Tr}$ & $\operatorname{Tr}$ & Tanpa revisi \\
\hline 6 & V & $\mathrm{CV}$ & Dp & Cdp & $\operatorname{Tr}$ & $\mathrm{Rk}$ & Revisi \\
\hline 7 & $\mathrm{~V}$ & $\mathrm{~V}$ & Dp & Dp & $\operatorname{Tr}$ & $\operatorname{Tr}$ & Tanpa revisi \\
\hline 8 & $\mathrm{~V}$ & V & Dp & Dp & $\mathrm{Rk}$ & $\mathrm{Rk}$ & Revisi \\
\hline 9 & $\mathrm{~V}$ & $\mathrm{CV}$ & $\mathrm{Dp}$ & Cdp & $\operatorname{Tr}$ & $\operatorname{Tr}$ & Tanpa revisi \\
\hline 10 & $\mathrm{~V}$ & $\mathrm{~V}$ & $\mathrm{Dp}$ & Dp & $\operatorname{Tr}$ & $\operatorname{Tr}$ & Tanpa revisi \\
\hline 11 & V & V & Dp & $\mathrm{Dp}$ & $\operatorname{Tr}$ & $\operatorname{Tr}$ & Tanpa revisi \\
\hline 12 & $\mathrm{CV}$ & V & $\mathrm{Cp}$ & Dp & $\operatorname{Tr}$ & $\operatorname{Tr}$ & Tanpa revisi \\
\hline 13 & $\mathrm{~V}$ & V & Dp & Dp & $\operatorname{Tr}$ & $\operatorname{Tr}$ & Tanpa revisi \\
\hline 14 & V & $\mathrm{CV}$ & Dp & Cdp & $\operatorname{Tr}$ & $\operatorname{Tr}$ & Tanpa revisi \\
\hline 15 & V & V & Dp & Dp & $\operatorname{Tr}$ & Rk & Revisi \\
\hline 16 & V & V & Dp & Dp & $\operatorname{Tr}$ & $\operatorname{Tr}$ & Tanpa revisi \\
\hline 17 & $\mathrm{~V}$ & V & Dp & Dp & $\operatorname{Tr}$ & $\operatorname{Tr}$ & Tanpa revisi \\
\hline 18 & V & V & Dp & Dp & $\operatorname{Tr}$ & $\operatorname{Tr}$ & Tanpa revisi \\
\hline 19 & V & V & $\mathrm{Dp}$ & Dp & $\operatorname{Tr}$ & $\operatorname{Tr}$ & Tanpa Revisi \\
\hline 20 & V & V & $\mathrm{Dp}$ & Dp & $\operatorname{Tr}$ & $\mathrm{Rk}$ & Revisi \\
\hline
\end{tabular}

Keterangan:

V : Valid

Dp : Dapat dipahami

Cdp : Cukup dapat dipahami

$\operatorname{Tr}$ : Tanpa revisi

Rk : Revisi kecil

Hasil validasi THB dari para validator menunjukkan bahwa tes hasil belajar valid dan dapat dipahami dengan dua puluh butir soal.

\section{Deskripsi Hasil Uji Coba.}

a. Tes Hasil Belajar

Tes hasil belajar dibuat berdasarkan kisi-kisi THB yang disesuaikan dengan tujuan pembelajaran yang hendak dicapai pada materi kenampakan alam dan buatan Indonesia dengan media video pembelajaran. Sebelum digunakan dalam penelitian, soal tes terlebih dahulu dilakukan uji validasi dan reabilitas. Hasil uji validitas dan reabilitas pada kegiatan uji coba adalah sebagai berikut. 
1) Uji Validitas

Tabel 3. Hasil Uji Validitas Tes Hasil Belajar

\begin{tabular}{llcc}
\hline No1 & Pearson Correlation & $\begin{array}{c}\text { Nilai Pearson } \\
\text { Correlation }(\mathbf{r})\end{array}$ & Keterangan \\
\hline No2 & Pearson Correlation & 0,612 & Valid \\
& & 0,312 & Tidak Valid/ \\
No3 & & Derbaiki \\
No4 & Pearson Correlation & 0,548 & Valid \\
No5 & Pearson Correlation & 0,508 & Valid \\
No6 & Pearson Correlation & 0,553 & Valid \\
No7 & Pearson Correlation & 0,478 & Valid \\
No8 & Pearson Correlation & 0,638 & Valid \\
No9 & Pearson Correlation & 0,612 & Valid \\
& & 0,402 & Tidak Valid/ \\
No10 & Pearson Correlation & 0,598 & Diperbaiki \\
No11 & Pearson Correlation & 0,543 & Valid \\
No12 & Pearson Correlation & 0,567 & Valid \\
No13 & Pearson Correlation & 0,537 & Valid \\
No14 & Pearson Correlation & 0,448 & Valid \\
No15 & Pearson Correlation & 0,562 & Valid \\
No16 & Pearson Correlation & 0,554 & Valid \\
No17 & Pearson Correlation & 0,568 & Valid \\
No18 & Pearson Correlation & 0,538 & Valid \\
No19 & Pearson Correlation & 0,556 & Valid \\
No20 & Pearson Correlation & 0,168 & Valid \\
& & & Tidak Valid/ \\
\hline & & & Gugur \\
\hline
\end{tabular}

Sumber: data yang sudah diolah.

Nilai validitas masing-masing butir soal memiliki nilai rhitung > rtabel dengan tingkat signifikansi 5\% adalah 0,444. Dapat disimpulkan bahwa butir pertanyaan tes hasil belajar dinyatakan "Valid" kecuali butir soal nomor 2, 9, dan 20 . Untuk butir soal nomor 2 dan 9 direvisi dan butir soal nomor 20 dianggap gugur sehingga tidak digunakan dalam penelitian.

2) Uji Reliabilitas

Untuk menganalisis data hasil uji coba THB peneliti menggunakan bantuan SPSS 17. Pengujian reliabilitas instrumen ini dilakukan bersamaan dengan pengujian validitas instrumen, karena validitas dan reliabel dapat dilaksanakan dalam sekali kegiatan. 
Tabel 4. Hasil Uji Reliabilitas Tes Hasil Belajar

Reliability Statistics

\begin{tabular}{|c|c|}
\hline Cronbach's Alpha & $\mathrm{N}$ of Items \\
\hline .739 & 19 \\
\hline
\end{tabular}

3) Deskripsi Hasil Penelitian

a. Hasil Penelitian Penggunaan Media Video Pembelajaran

(1) Hasil Pengamatan dan Reliabilitas Pelaksanaan Pembelajaran dengan Penggunaan Media Video Pembelajaran

\begin{tabular}{|c|c|c|c|c|c|}
\hline \multirow[t]{2}{*}{ No } & \multirow[t]{2}{*}{ Aspek yang Diamati } & \multicolumn{2}{|c|}{ RPP (1) } & \multirow{2}{*}{$\begin{array}{l}\text { Rata- } \\
\text { rata }\end{array}$} & \multirow[t]{2}{*}{ Kategori } \\
\hline & & $\overline{P I}$ & PII & & \\
\hline I & Pra Pembelajaran & 3,69 & 3,33 & 3,51 & Baik \\
\hline II & Pembukaan Pembelajaran & 3,00 & 3,46 & 3,23 & Baik \\
\hline III & Kegiatan inti Pembelajaran & 4,00 & 4,00 & 4,00 & Baik \\
\hline \multirow[t]{3}{*}{ IV } & Penutup & 3,50 & 4,00 & 3,75 & Baik \\
\hline & & 14,19 & 14,79 & 14,49 & Baik \\
\hline & Reliabilitas & & 98,62 & \multicolumn{2}{|c|}{ Reliabel } \\
\hline \multirow[t]{2}{*}{ No } & Aspek yang Diamati & \multicolumn{2}{|c|}{ RPP (2) } & Rata- & Kategori \\
\hline & & $\overline{\mathrm{PI}}$ & PII & rate & \\
\hline I & Pra Pembelajaran & 4,00 & 3,00 & 3,50 & Baik \\
\hline II & $\begin{array}{l}\text { Pembukaan } \\
\text { Pembelajaran }\end{array}$ & 3,69 & 3,77 & 3,73 & Baik \\
\hline III & $\begin{array}{l}\text { Kegiatan inti } \\
\text { Pembelajaran }\end{array}$ & 4,00 & 4,00 & 4,00 & Baik \\
\hline \multirow[t]{3}{*}{ IV } & Penutup & 3,00 & 3,67 & 3,34 & Baik \\
\hline & & 14,69 & 14,44 & 14,57 & Baik \\
\hline & Reliabilitas & 93,99 & & \multicolumn{2}{|c|}{ Reliabel } \\
\hline
\end{tabular}

Sumber: data yang sudah diolah

Rata-rata kemampuan guru dalam melaksanakan pembelajaran dengan menggunakan media video pembelajaran materi kenampakan alam dan buatan Indonesia didapat data reliabilitasnya adalah RPP I yaitu 98,62\% dan RPP II yaitu 93,99\%, sedangkan rata-rata kemampuan guru antara 3 sampai 4, maka kemampuan guru dalam mengelola pembelajaran sudah dapat dikatakan baik, dan reliabilitasnya di atas $75 \%$. Hal ini berarti instrumen yang digunakan reliabel. Hasil dari pengamatan pengelolaan pembelajaran ini hanya digunakana sebagai data pendukung dalam penelitian. 
(2) Hasil Belajar Siswa

Tabel 5. Hasil Belajar dengan Penggunaan Media Video Pembelajaran

\begin{tabular}{ccrrrr}
\hline No & Nama & \multicolumn{2}{c}{ Skor } & \multicolumn{2}{c}{ Ketuntasan Belajar } \\
\cline { 3 - 6 } & siswa & Pretest & Postest & Pretest & Postest \\
$\mathbf{1}$ & AK & 50 & 88 & Tidak Tuntas & Tuntas \\
$\mathbf{2}$ & AZ & 50 & 95 & Tidak Tuntas & Tuntas \\
$\mathbf{3}$ & BD & 50 & 92 & Tidak Tuntas & Tuntas \\
$\mathbf{4}$ & DP & 50 & 89 & Tidak Tuntas & Tuntas \\
$\mathbf{5}$ & GR & 75 & 85 & Tuntas & Tuntas \\
& & & & & \\
$\mathbf{6}$ & GS & 50 & 78 & Tidak Tuntas & Tuntas \\
$\mathbf{7}$ & KH & 68 & 89 & Tuntas & Tuntas \\
$\mathbf{8}$ & MD & 55 & 100 & Tidak Tuntas & Tuntas \\
$\mathbf{9}$ & MP & 60 & 95 & Tidak Tuntas & Tuntas \\
$\mathbf{1 0}$ & MR & 76 & 87 & Tuntas & Tuntas \\
$\mathbf{1 1}$ & MA & 54 & 100 & Tidak Tuntas & Tuntas \\
$\mathbf{1 2}$ & MD & 52 & 90 & Tidak Tuntas & Tuntas \\
$\mathbf{1 3}$ & MH & 50 & 86 & Tidak Tuntas & Tuntas \\
$\mathbf{1 4}$ & MS & 51 & 90 & Tidak Tuntas & Tuntas \\
$\mathbf{1 5}$ & PW & 50 & 87 & Tidak Tuntas & Tuntas \\
& & Rata-rata & $\mathbf{5 6 , 0 5}$ & $\mathbf{9 0 , 0 6}$ & \\
\hline
\end{tabular}

Sumber: data yang sudah diolah

Hasil pretest siswa yang diberikan pada pembelajaran dengan penggunaan media video pembelajaran memiliki nilai pretest rata-rata 58,06 dengan nilai minimum 50 dan nilai maksimum 76 , hasil postest setelah penggunaan media video pembelajaran nilai rata-rata 90,06 dengan nilai minimum 78 dan nilai maksimum 100.

b. Hasil Penelitian Penggunaan Metode Ceramah Pada Kelas Control

(1) Hasil Pengamatan dan Reliabilitas Pelaksanaan Pembelajaran Dengan Menggunakan Metode Ceramah

\begin{tabular}{clcccc}
\hline No & Aspek yang Diamati & \multicolumn{2}{c}{ RPP I } & Rata-rata & Kategori \\
\cline { 3 - 4 } & & PI & PII & & \\
I & Pra Pembelajaran & 0,33 & 3,33 & 1,83 & Baik \\
II & Pembukaan Pembelajaran & 3,38 & 3,31 & 3,35 & Baik \\
III & Kegiatan inti Pembelajaran & 4 & 4 & 4 & Baik \\
IV & Penutup & 4 & 4 & 4 & Baik \\
& \multirow{2}{*}{ Reliabilitas } & 11,17 & 14,64 & 13,18 & Baik \\
& \multirow{2}{*}{88,88} & \multicolumn{2}{c}{ Reliabel } \\
\hline
\end{tabular}

Sumber: data yang sudah diolah 


\begin{tabular}{|c|c|c|c|c|c|}
\hline \multirow[t]{2}{*}{ No } & \multirow{2}{*}{ Aspek yang Diamati } & \multicolumn{2}{|c|}{ RPP II } & \multirow[t]{2}{*}{ Rata-rata } & \multirow[t]{2}{*}{ Kategori } \\
\hline & & $\overline{P I}$ & $\overline{\mathrm{PII}}$ & & \\
\hline I & Pra Pembelajaran & 4,00 & 3,31 & 3,65 & Baik \\
\hline II & Pembukaan Pembelajaran & 3,33 & 3,50 & 3,42 & Baik \\
\hline III & Kegiatan inti Pembelajaran & 3,38 & 4,00 & 3,69 & Baik \\
\hline \multirow[t]{3}{*}{ IV } & Penutup & 3,50 & 3,00 & 3,25 & Baik \\
\hline & & 14,21 & 13,81 & 14,01 & Baik \\
\hline & Reliabilitas & \multicolumn{2}{|c|}{98,57} & & Reliabel \\
\hline
\end{tabular}

Sumber : Data yang sudah diolah

Rata-rata kemampuan guru dalam melaksanakan pembelajaran dengan metode ceramah reliabilitasnya adalah pada RPP I yaitu 88,88\% dan RPP II yaitu 98,57, sedangkan rata-rata kemampuan guru antara 3 sampai 4, maka kemampuan guru dalam mengelola pembelajaran sudah dapat dikatakan baik, dan relibialitasnya di atas $75 \%$ ini berarti instrumen yang digunakan reliabel. Hasil dari pengamatan pengelolahan pembelajaran ini hanya digunakan sebagai data pendukung dalam penelitian.

(2) Hasil Belajar Siswa Dengan Metode Ceramah

\begin{tabular}{|c|c|c|c|c|c|}
\hline \multirow[t]{2}{*}{ No } & \multirow[t]{2}{*}{ Nama siswa } & \multicolumn{2}{|l|}{ Skor } & \multicolumn{2}{|c|}{ Ketuntasan Belajar } \\
\hline & & Pretest & Postest & Pretest & Postest \\
\hline 1 & BI & 50 & 80 & Tidak Tuntas & Tuntas \\
\hline 2 & NB & 50 & 74 & Tidak Tuntas & Tidak Tuntas \\
\hline 3 & RW & 50 & 68 & Tidak Tuntas & Tidak Tuntas \\
\hline 4 & RM & 50 & 70 & Tidak tuntas & Tidak Tuntas \\
\hline 5 & RH & 75 & 76 & Tidak Tuntas & Tuntas \\
\hline 6 & SN & 50 & 70 & Tidak Tuntas & Tidak Tuntas \\
\hline 7 & SO & 68 & 74 & Tidak Tuntas & Tidak Tuntas \\
\hline 8 & TA & 55 & 80 & Tidak Tuntas & Tuntas \\
\hline 9 & TA & 60 & 80 & Tidak Tuntas & Tuntas \\
\hline 10 & $\mathrm{TC}$ & 76 & 74 & Tidak Tuntas & Tidak Tuntas \\
\hline 11 & TW & 54 & 72 & Tidak Tuntas & Tidak Tuntas \\
\hline 12 & UA & 52 & 70 & Tidak Tuntas & Tidak Tuntas \\
\hline 13 & UW & 50 & 76 & Tidak Tuntas & Tuntas \\
\hline 14 & VA & 51 & 88 & Tidak Tuntas & Tuntas \\
\hline \multirow[t]{2}{*}{15} & YA & 50 & 82 & Tidak Tuntas & Tuntas \\
\hline & & Rate & & 75,65 & \\
\hline
\end{tabular}

Hasil pretest siswa pada pembelajaran menggunakan metode ceramah diperoleh hasil pretest nilai rata-rata 56,05 dengan nilai maksimum 76 dan minimum 50. Hasil posttest setelah menggunakan metode ceramah nilai rata-rata 75,65 dengan nilai minimum 68 dan nilai maksimum 88. Dari hasil pretest siswa tidak tuntas. Setelah dilakukan pembelajaran dengan menggunakan metode ceramah, sebagian siswa mencapai ketuntasan dalam belajar namun ada juga sebagian siswa yang tidak tuntas dalam belajar. 


\section{ELSE (Elementary School Education Journal) \\ Volume 3 Nomor 2 Agustus 2019 \\ P-ISSN: 2581-1800 E-ISSN: 2597-4122 \\ Email: else@um-surabaya.ac.id}

4) Analisis Statistik

Dari data hasil penyebaran instrumen kemudian diberikan penilaian setiap jawaban, selanjutnya dijadikan sebagai bahan perhitungan dalam penelitian ini. Hasil dari pengumpulan data dari variabel merupakan skor mentah. Pada uji statistik skor mentah diubah menjadi skor baku yang dijadikan dasar uji asumsi statistik berupa uji normalitas dan homogenitas yang merupakan syarat uji statistik dengan uji-t.

a. Uji Normalitas

Uji normalitas data hasil belajar menggunakan bantuan komputer program SPSS 17.00 for windows dengan teknik One Sample Kolmogorov-Smirnov pada taraf signifikansi ( $\alpha$ ) 0,05 . Adapun hasil uji normalitas adalah sebagai berikut.

Tabel 6. Hasil Uji Normalitas

\begin{tabular}{llll}
\hline Variabel & Kelas & $\begin{array}{l}\text { Kolmogorov- } \\
\text { Smirnov }\end{array}$ & Sig \\
& & 0,593 & \\
\hline Hasil belajar (pretest) & Kontrol & 0,723 & 0,873 \\
Hasil belajar (posttest) & & 0,644 & 0,673 \\
Hasil belajar (pretest) & Eksperimen & 0.655 & 0,801 \\
Hasil belajar (posttest) & & & 0,784
\end{tabular}

Sumber : Data yang sudah diolah

Tabel di atas menunjukkan bahwa asumsi normalitas sudah terpenuhi terlihat dari tingkat signifikan pada variabel hasil belajar pada kelas kontrol dan eksperimen lebih dari $5 \%$.

\section{b. Uji Homogenitas}

Untuk menguji perbedaan hasil belajar dan keterampilan sosial siswa pada kelas ekperimen dan kelas kontrol, digunakan uji Independent sample $t$ test. Sebelum dilakukan Independent sample t test, perlu diketahui uji homogenitas varians. Adapun hasil uji homogenitas pada penelitian ini adalah sebagai berikut.

Tabel 7. Hasil Uji Homogenitas

\begin{tabular}{llll}
\hline Variabel & & Kolmogorov-Smirnov & Sig \\
\hline $\begin{array}{l}\text { Hasil } \\
\text { (pretest) }\end{array}$ & belajar & 0,164 & 0,687 \\
$\begin{array}{l}\text { Hasil } \\
\text { (posttest) }\end{array}$ & belajar & 0,272 & 0,605 \\
\hline
\end{tabular}

Sumber : Data yang sudah diolah 


\section{ELSE (Elementary School Education Journal) \\ Volume 3 Nomor 2 Agustus 2019 \\ P-ISSN: 2581-1800 E-ISSN: 2597-4122 \\ Email: else@um-surabaya.ac.id}

Berdasarkan tabel di atas tampak nilai signifikan untuk masing-masing variabel lebih dari $0,05 \%$ yang berarti Ho ditolak yang artinya varians kedua sampel (kelas) adalah homogen, sehingga asumsi independent sample t test terpenuhi.

c. Pengujian Hipotesis

Pengujian hipotesis dimaksudkan untuk menguji ada atau tidaknya pengaruh penggunakan media video pembelajaran terhadap hasil belajar siswa. Untuk mengetahui hasil $t_{\text {hitung }}$ yang diperoleh dikonsultasikan dengan $t_{\text {tabel }}$ dengan taraf signifikan $5 \%$

Tabel 8. Hasil Uji T Hasil Belajar Siswa

Group Statistics

\begin{tabular}{|c|c|c|c|c|c|}
\hline & Kelompok & Mean & & ation & Std.Error Mean \\
\hline Hasil Belajar & Kontrol & 15 & 48.9800 & 4.41191 & .98749 \\
\hline Postest & Eksperimen & 15 & 59.8400 & 4.96694 & 1.11032 \\
\hline
\end{tabular}

Independent Samples Test

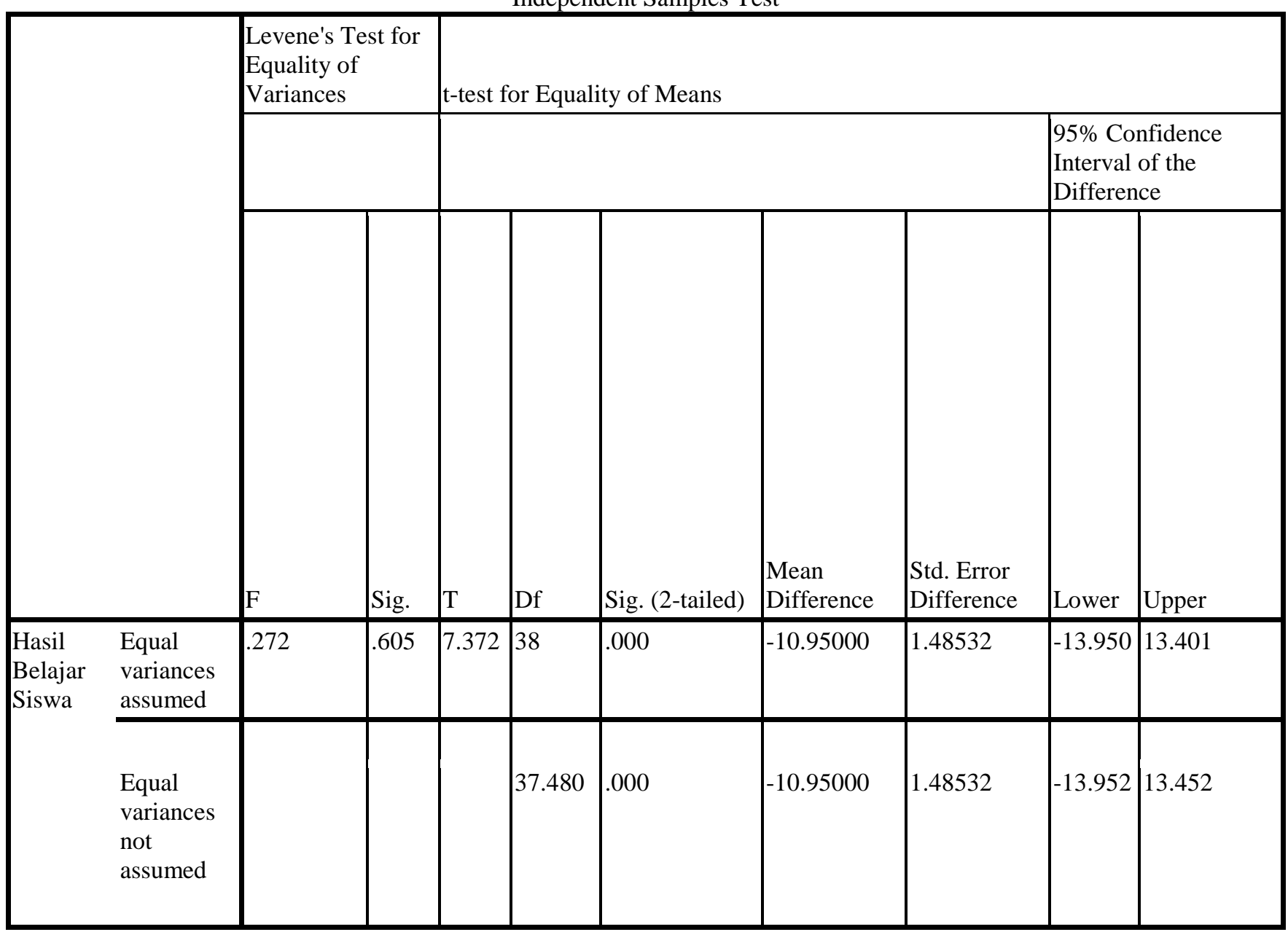

Sumber: data yang sudah diolah 


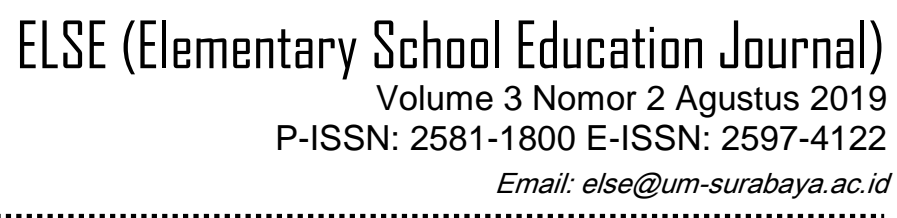

Hasil analisis menunjukkan jumlah data valid ada 30 terdiri dari 15 siswa pada kelas eksperimen dan 15 siswa pada kelas kontrol. Nilai rata-rata 48,9800 untuk Siswa pada kelas kontrol dan 59,8400 untuk kelas eksperimen. Standar deviasi pada kelas kontrol 4,41191 untuk kelas kontrol dan 4,96694 untuk kelas eksperimen. Sedangkan F sebesar 0,272 dengan nilai signifikan $(0,605)<\alpha(0,05)$, maka $\mathrm{H}_{0}$ diterima, berarti kedua sampel memiliki varian yang sama (homogen). Hasil analisis dengan uji Independent Sample T test sampel independen diperoleh sig. sebesar $0,000<\alpha 0,05$ dengan $t$ sebesar 7,372, kemudian hasil $t_{\text {hitung }}$ dikonsultasikan dengan $t_{\text {tabel }}$ untuk uji satu pihak dimana $t_{\text {tabel }} 1,684(\mathrm{~N}=30)$ karena $t_{\text {hitung }}>t_{\text {tabel }}$ berarti hasil kedua sampel berbeda secara signifikan.

Berdasarkan data hasil di atas, terbukti bahwa data hasil belajar siswa yang mengikuti pembelajaran dengan menggunakan media video pembelajaran materi keragaman kenampakan alam dan buatan Indonesia lebih baik dari pada hasil belajar siswa yang mengikuti pembelajaran dengan menggunakan metode ceramah.

\section{KESIMPULAN DAN SARAN}

Berdasarkan hasil penelitian yang disajikan pada pembahasan sehingga dapat disimpulkan bahwa Penggunaan media video pembelajaran berpengauh terhadap hasil belajar IPS materi keragaman kenampakan alam dan buatan Indonesia pada siswa kelas V Sekolah Dasar. Hal ini telah dibuktikan dengan Data-data yang telah berhasil dikumpulkan kemudian dianalisa dengan analisis Uji t dengan memanfaatkan komputer dengan sistem seri program statistik (SPSS version 17). Hasil uji hipotesis pertama menunjukkan bahwa hasil belajar siswa pada kelas eksperimen lebih tinggi dibandingkan pada kelas kontrol. Hal ini ditunjukkan oleh nilai sig. sebesar $0,000<\alpha 0,05$ dan $t_{\text {hitung }}(7,372)<t_{\text {tabel }}(1,684)$ dengan nilai mean sebesar 59.8400 dibandingkan dengan hasil belajar siswa dengan menggunakan metode ceramah yaitu 48,9800. Dengan demikian dapat disimpulkan bahwa media video pembelajaran berpengaruh terhadap hasil belajar IPS materi keragaman kenampakan alam dan buatan Indonesia pada siswa kelas V Sekolah Dasar secara signifikan.

Namun, pembelajaran dengan penggunaan media video pembelajaran diperlukan managemen waktu yang tepat serta persiapan yang matang sehingga efektivitas waktu dan output hasil kegiatan belajar mengajar yang sudah diterapkan dapat sesuai dengan harapan. 


\section{ELSE (Elementary Schod Education Journal) \\ Volume 3 Nomor 2 Agustus 2019 \\ P-ISSN: 2581-1800 E-ISSN: 2597-4122 \\ Email: else@um-surabaya.ac.id}

Penggunaan media video pembelajaran dapat meningkatkan dan memicu motivasi seorang guru dalam berkreativitas sehingga kegiatan pembelajaran lebih berwarna dan yang terpenting adalah membuat para siswa merasa senang dan termotivasi untuk lebih giat dalam belajar IPS.

\section{DAFTAR PUSTAKA}

Arif S, Sadiman. 2009. Media Pendidikan. Jakarta: PT. Raja Grafindo Persada.

Arikunto,Suharsimi. 1989. Prosedur Penelitian suatu Pendekatan Praktik. Jakarta: Rineka Cipta.

Asyhar. 2011. Kreatif Mengembangkan Media Pembelajaran, Jakarta: Gaung Persada (GP) Press.

Azhar Arsyad. 2011. Media Pembelajaran. Jakarta: PT. Raja Grafindo Persada.

Bahri, Djamarah, dan Aswan Zain. 2006. Strategi Belajar Mengajar. Jakarta: Rineka Cipta.

Dimyati, Mudjiono. 2006. Belajar dan Pembelajarn. Jakarta: Penerbit Rineka.

H.C, Cheppy. 2005. Strategi Ilmu Pengetahuan Sosial. Surabaya: Karya Anda Syaiful.

Hadfield, J. 1986. Harap'As communication games. Australia: Thomas Nelson and Son Ltd.

Hamalik, Oemar. 2006. Teknologi Dalam Pendidika. Bandung: Yayasan Partisipsi Pembangunan Nasional.

Kattington, L.E. 2010. Handbook of curriculum development. New York: Nova Science Publisher, Inc.

Purwanto, Ngalim. 2008. Prinsip-Prinsip Dan Teknik Evaluasi Pengajaran. Bandung :Remaja Rosda Karya.

Sudjana, Nana. 2005. Penelitian Proses Hasil Belajar Mengajar. Bandung : Remaja Rosdakarya.

Sudjana, Nana. 2005. Dasar-Dasar Proses Belajar Mengajar. Bandung: Sinar Baru Algensindo.

Sugiyono. 2012. Metode Penelitian Kuantitatif dan R \& D. Bandung. Alfabeta.

Suhanadji dan Waspodo. 2003. Pendidikan IPS. Surabaya : Insan Cendekia. 
Yun, Chung-il. 2007. Teacher's Primary Role for Education Reform: Equalizing Learning Outcomes. Korea: Seoul National University Korea. 